\title{
A New Equation to Estimate Glomerular Filtration Rate
}

\author{
Andrew S. Levey, MD; Lesley A. Stevens, MD, MS; Christopher H. Schmid, PhD; Yaping (Lucy) Zhang, MS; Alejandro F. Castro III, MPH; \\ Harold I. Feldman, MD, MSCE; John W. Kusek, PhD; Paul Eggers, PhD; Frederick Van Lente, PhD; Tom Greene, PhD; and \\ Josef Coresh, MD, PhD, MHS, for the CKD-EPI (Chronic Kidney Disease Epidemiology Collaboration)*
}

Background: Equations to estimate glomerular filtration rate (GFR) are routinely used to assess kidney function. Current equations have limited precision and systematically underestimate measured GFR at higher values.

Objective: To develop a new estimating equation for GFR: the Chronic Kidney Disease Epidemiology Collaboration (CKD-EPI) equation.

Design: Cross-sectional analysis with separate pooled data sets for equation development and validation and a representative sample of the U.S. population for prevalence estimates.

Setting: Research studies and clinical populations ("studies") with measured GFR and NHANES (National Health and Nutrition Examination Survey), 1999 to 2006.

Participants: 8254 participants in 10 studies (equation development data set) and 3896 participants in 16 studies (validation data set). Prevalence estimates were based on 16032 participants in NHANES.

Measurements: GFR, measured as the clearance of exogenous filtration markers (iothalamate in the development data set; iothalamate and other markers in the validation data set), and linear regression to estimate the logarithm of measured GFR from standardized creatinine levels, sex, race, and age.
Results: In the validation data set, the CKD-EPI equation performed better than the Modification of Diet in Renal Disease Study equation, especially at higher GFR $(P<0.001$ for all subsequent comparisons), with less bias (median difference between measured and estimated GFR, 2.5 vs. $5.5 \mathrm{~mL} / \mathrm{min}$ per $1.73 \mathrm{~m}^{2}$ ), improved precision (interquartile range [IQR] of the differences, 16.6 vs. 18.3 $\mathrm{mL} / \mathrm{min}$ per $1.73 \mathrm{~m}^{2}$ ), and greater accuracy (percentage of estimated GFR within $30 \%$ of measured GFR, $84.1 \%$ vs. $80.6 \%$ ). In NHANES, the median estimated GFR was $94.5 \mathrm{~mL} / \mathrm{min}$ per 1.73 $\mathrm{m}^{2}$ (IQR, 79.7 to 108.1$)$ vs. 85.0 (IQR, 72.9 to 98.5$) \mathrm{mL} / \mathrm{min}$ per $1.73 \mathrm{~m}^{2}$, and the prevalence of chronic kidney disease was $11.5 \%$ (95\% Cl, $10.6 \%$ to $12.4 \%$ ) versus $13.1 \%(\mathrm{Cl}, 12.1 \%$ to $14.0 \%)$.

Limitation: The sample contained a limited number of elderly people and racial and ethnic minorities with measured GFR.

Conclusion: The CKD-EPI creatinine equation is more accurate than the Modification of Diet in Renal Disease Study equation and could replace it for routine clinical use.

Primary Funding Source: National Institute of Diabetes and Digestive and Kidney Diseases.

Ann Intern Med. 2009;150:604-612.

www.annals.org

For author affiliations, see end of text.

* For a list of other CKD-EPI staff and collaborators, see the Appendix (available at www.annals.org).
C linical assessment of kidney function is part of routine medical practice for adults and is essential for assessing overall health; interpreting signs and symptoms; selecting the correct dosage for drugs that are excreted by the kidneys; preparing for invasive diagnostic or therapeutic procedures; and detecting, evaluating, and monitoring acute and chronic kidney diseases. The glomerular filtration rate (GFR) is considered the best overall index of kidney function in health and disease. The GFR cannot be measured easily in clinical practice; instead, it is estimated from equations by using serum creatinine level, age, race, sex, and body size $(1,2)$. One such equation, the MDRD (Modification of Diet in Renal Disease) Study equation, has

See also:

Print

Editors' Notes. . . . . . . . . . . . . . . . . . . . . . . 605

Web-Only

Appendix

Appendix Tables

Appendix Figures

Conversion of graphics into slides gained widespread acceptance $(3,4)$, and most clinical laboratories estimate GFR by using this equation when serum creatinine measurement is ordered (5). The MDRD Study equation is also used to assess the burden of chronic kidney disease in epidemiologic studies and public health (6). The prevalence of chronic kidney disease in the United States has increased from approximately 10\% in 1988 to 1994 to $13 \%$ in 1999 to 2004 , which corresponds to approximately 26.3 million people in $2000(6,7)$.

The MDRD Study equation was developed by studying people with chronic kidney disease, and as such, its major limitations are imprecision and systematic underestimation of measured GFR (bias) at higher values (8). We sought to develop and validate a new estimating equation based on the serum creatinine level that would be as accurate as the MDRD Study equation at a GFR less than 60 $\mathrm{mL} / \mathrm{min}$ per $1.73 \mathrm{~m}^{2}$ and more accurate at a higher GFR. We report development and validation of a new equation and compare it with the MDRD Study equation for estimating measured GFR and U.S. prevalence of chronic kidney disease.

\section{Methods}

The CKD-EPI (Chronic Kidney Disease Epidemiology Collaboration) is a research group established by the National Institute of Diabetes and Digestive and Kidney

604 (C) 2009 American College of Physicians 
Diseases. The institutional review boards of all participating institutions approved the study. The Appendix (available at www.annals.org) provides details about study selection and analytical methods.

\section{Data Sources}

Investigators collaborating with CKD-EPI provided data from research studies and clinical populations (hereafter referred to as "studies"). In brief, we identified studies from the MEDLINE database and through investigators' and collaborators' contacts (Appendix Figure 1, available at www.annals.org). Key inclusion criteria were measurement of GFR on the basis of exogenous filtration markers and ability to calibrate serum creatinine assay. We restricted ourselves to studies that used urinary clearance of iothalamate for development and internal validation of equations, but included studies that used iothalamate and other filtration markers for external validation. We randomly divided 10 studies ( 6 research studies and 4 clinical populations) (3,9-15), comprising 8254 participants, into separate data sets for development (5504 participants) and internal validation (2750 participants) (Appendix Table 1, available at www.annals.org). We used 16 other studies (6 research studies and 10 clinical populations) $(13,16-28)$, comprising 3896 participants, for external validation (Appendix Table 2, available at www.annals.org).

\section{Laboratory Methods}

For all studies, we recalibrated serum creatinine values to standardized creatinine measurements by using the Roche enzymatic method (Roche-Hitachi P-Module instrument with Roche Creatininase Plus assay, Hoffman-La Roche, Basel, Switzerland) at the Cleveland Clinic Research Laboratory (Cleveland, Ohio) as described elsewhere (29, 30). We compared new equations with the MDRD Study equation (estimated GFR $=175 \times$ standardized $\mathrm{S}_{\mathrm{cr}}{ }^{-1.154} \times$ age $^{-0.203} \times 1.212$ [if black] $\times 0.742$ [if female]), in which GFR is expressed as $\mathrm{mL} / \mathrm{min}$ per $1.73 \mathrm{~m}^{2}$ of body surface area and $S_{\mathrm{cr}}$ is expressed in $\mathrm{mg} / \mathrm{dL}$ (4).

\section{Analyses in the Development Data Set}

We prespecified a process for developing equations that uses transformations of continuous variables and the inclusion of additional variables and interactions to develop a large number of candidate equations. We used least-squares linear regression to relate measured GFR to serum creatinine and clinical characteristics available in all databases. Predictor variables included serum creatinine, age, race (black vs. white and other), and sex in all models, as in the MDRD Study equation, and additional variables in some models (diabetes [yes/no], previous organ transplantation [yes/no], and weight, as assigned by the individual studies). We fit regression models to all patients in the pooled development data set without accounting for study in the models. We transformed GFR and serum creatinine to natural logarithms to reflect their multiplicative (inverse) relationship and to stabilize variance across the range of GFR.

\section{Context}

The MDRD (Modification of Diet in Renal Disease) Study equation is commonly used to estimate glomerular filtration rate (GFR), but it is imprecise and underestimates GFR at higher values.

\section{Contribution}

These researchers pooled data from studies to develop and validate a new equation, the CKD-EPI (Chronic Kidney Disease Epidemiology Collaboration) equation, to predict GFR. The CKD-EPI equation was somewhat more precise and accurate than the MDRD Study equation, especially at higher GFRs. Using the new equation could decrease false-positive results-the mislabeling of people with high GFR as having poor kidney function.

\section{Caution}

The sample used to develop the CKD-EPI equation included few elderly and nonwhite persons. Evaluation of the equation in these populations is needed.

-The Editors

We determined appropriate transformations of log serum creatinine and age by first fitting nonparametric smoothing splines to characterize the shape of the relationship of these factors with mean log measured GFR and then creating piecewise linear splines to correspond to observed nonlinearity (Appendix Table 3, available at www.annals.org) (31). We included additional variables and pairwise interactions between them if they were significant $(P<0.010$ for additional variables and $P<0.001$ for interactions) and improved model performance (relative reduction in root mean square error $\geq 2 \%$ ) (Appendix Table 4, available at www.annals.org).

\section{Analyses in the Internal Validation Data Set}

We verified the statistical significance of predictor variables and interactions for all models and the relative ranking of performance among models. We derived final coefficients for each model by combining the development and internal validation data sets.

\section{Analyses in the External Validation Data Set}

We compared performance of the multiple models developed in the development data set with each other as well as with the MDRD Study equation by using a prespecified process. We performed comparisons in the overall data set and in subgroups defined by estimated GFR, clinical characteristics, and type of filtration marker (iothalamate vs. noniothalamate). We ranked equations on performance and ease of application. We performed sensitivity analyses for all steps to evaluate the robustness of results across studies. We selected a single model as the best equation for general use, referred to here as the "CKD-EPI equation."

\section{Metrics for Equation Performance}

We compared measured and estimated GFR for each patient graphically by plotting measured GFR and 
ARTICLE Development and Comparison of a New Equation to Estimate GFR

Table 1. Patient Characteristics

\begin{tabular}{|c|c|c|c|c|}
\hline Characteristic & $\begin{array}{l}\text { Development } \\
\text { Data Set }(n=5504)\end{array}$ & $\begin{array}{l}\text { Internal Validation } \\
\text { Data Set }(n=2750)\end{array}$ & $\begin{array}{l}\text { External Validation } \\
\text { Data Set }(n=3896)\end{array}$ & $P$ Value* \\
\hline Mean age (SD), $y$ & $47(15)$ & $47(15)$ & $50(15)$ & $<0.001$ \\
\hline Age, $n(\%)$ & & & & $<0.001$ \\
\hline$<40$ y & $2058(37)$ & $1018(37)$ & $1136(29)$ & \\
\hline $41-65$ y & $2751(50)$ & $1403(51)$ & $2192(56)$ & \\
\hline$>65 y$ & 695 (13) & $329(12)$ & $568(15)$ & \\
\hline $66-70$ y & $476(9)$ & $220(8)$ & $254(7)$ & \\
\hline $71-75$ y & $150(3)$ & $66(2)$ & $185(5)$ & \\
\hline $76-80 y$ & $41(0)$ & $30(1)$ & $92(2)$ & \\
\hline$>80 y$ & $28(0)$ & $13(0)$ & $37(0)$ & \\
\hline Women, $n(\%)$ & $2391(43)$ & $1215(44)$ & $1767(45)$ & 0.084 \\
\hline Race, $n(\%)$ & & & & 0.001 \\
\hline Black & $1728(32)$ & $857(31)$ & $384(10)$ & \\
\hline Hispanic & $247(5)$ & $106(4)$ & $67(2)$ & \\
\hline Asian & $62(1)$ & $38(1)$ & $67(2)$ & \\
\hline White or other & $3467(63)$ & $1749(64)$ & $3378(87)$ & \\
\hline Kidney donor, $n(\%)$ & $694(13)$ & $336(12)$ & $608(16)$ & $<0.001$ \\
\hline Transplant recipient, $n(\%)$ & $241(4)$ & $119(4)$ & $1134(29)$ & $<0.001$ \\
\hline Diabetes, $n(\%)$ & $1581(29)$ & $825(30)$ & $1089(28)$ & 0.173 \\
\hline Mean height (SD), $\mathrm{cm}$ & $170(10)$ & $170(10)$ & $170(10) \dagger$ & 0.90 \\
\hline Mean weight (SD), $\mathrm{kg}$ & $82(20)$ & $82(20)$ & $79(18)$ & $<0.001$ \\
\hline Mean body mass index (SD), $\mathrm{kg} / \mathrm{m}^{2}$ & $28(6)$ & $28(6)$ & $27(6) \dagger$ & $<0.001$ \\
\hline Mean body surface area (SD), $m^{2}$ & $1.93(0.20)$ & $1.93(0.20)$ & $1.90(0.23) \dagger$ & $<0.001$ \\
\hline Mean GFR (SD), $\mathrm{mL} / \mathrm{min}$ per $1.73 \mathrm{~m}^{2} \ddagger$ & $68(40)$ & $67(40)$ & $68(36)$ & 0.70 \\
\hline Mean serum creatinine level (SD) & & & & $<0.001$ \\
\hline$\mu \mathrm{mol} / \mathrm{L}$ & $146(106)$ & $148(106)$ & $134(88)$ & \\
\hline$m g / d L$ & $1.65(1.20)$ & $1.67(1.20)$ & $1.52(1.00)$ & \\
\hline
\end{tabular}

GFR $=$ glomerular filtration rate.

* For comparison of the combined development and internal validation data sets vs. the external validation data set.

† The sample size is 3875 because of missing data.

\# To convert GFR from $\mathrm{mL} / \mathrm{min}$ per $1.73 \mathrm{~m}^{2}$ to $\mathrm{mL} / \mathrm{s}$ per $\mathrm{m}^{2}$, multiply by 0.0167 .

the difference (measured GFR - estimated GFR) against estimated GFR. We assessed bias as the median difference, with positive values indicating an underestimation of measured GFR. We assessed precision as interquartile range (IQR) for the differences. We assessed accuracy as root mean square error, relative to measured GFR and the percentage of estimates within $30 \%$ of the measured GFR $\left(\mathrm{P}_{30}\right)$, which takes into account greater errors at higher values and the absolute values of the difference between measured and estimated GFR. We calculated CIs by bootstrap methods (2000 bootstraps) (32) for median differences and IQR of the differences and by the binomial method for $\mathrm{P}_{30}$. We computed receiver-operating characteristic (ROC) curves for measured GFR less than 90, 75, 60, 45, 30, and $15 \mathrm{~mL} / \mathrm{min}$ per $1.73 \mathrm{~m}^{2}$. We defined GFR stages as greater than 90,60 to 89,30 to 59,15 to 29 , and less than $15 \mathrm{~mL} / \mathrm{min}$ per $1.73 \mathrm{~m}^{2}(1)$. We compared sensitivity, specificity, and concordance between estimated and measured GFR among equations by using the McNemar test. We compared concordance of estimated GFR stages among equations by using the sign test.

We used R, version 2 (Free Software Foundation, Boston, Massachusetts), and SAS, version 9.1 (SAS Institute, Cary, North Carolina), to compute all analyses.

\section{Estimation of U.S. Prevalence}

The NHANES (National Health and Nutrition Examination Survey) is a cross-sectional, multistage, stratified, clustered probability sample of the civilian, noninstitutionalized population of the United States conducted by the National Center of Health Statistics and appropriate for estimates of prevalence of chronic conditions in the United States. We analyzed data from the 1999 to 2000, 2001 to 2002, 2003 to 2004, and 2005 to 2006 surveys. We limited our study population to 16032 participants (3754 from 1999 to 2000, 4297 from 2001 to 2002, 4017 from 2003 to 2004, and 3964 from 2005 to 2006) who were 20 years or older, had completed the examination in the mobile examination center, were not pregnant or menstruating, were not missing serum creatinine measurements, and did not have an estimated GFR less than $15 \mathrm{~mL} / \mathrm{min}$ per $1.73 \mathrm{~m}^{2}$. Our methods are similar to those used in previous studies (7).

The NHANES did not measure GFR. We measured serum creatinine by using a kinetic-rate Jaffe method and recalibrated results to standardized creatinine measurements obtained at the Cleveland Clinic Research Laboratory (33). We estimated GFR by using the MDRD Study equation and the newly developed CKD-EPI equation. We truncated estimates that exceeded $200 \mathrm{~mL} / \mathrm{min}$ per 1.73 $\mathrm{m}^{2}$ at that level. Methods for collection, analysis, and reporting for albuminuria are described elsewhere $(7,34)$. 
We defined albuminuria as an albumin-to-creatinine ratio greater than $30 \mathrm{mg} / \mathrm{g}$. We used repeated measurements, obtained approximately 2 weeks after the original examination in a subset of 1241 participants in NHANES from 1988 to 1994 , to estimate the persistence of albuminuria (34). The NHANES data do not include accurate diagnoses of the causes of kidney disease. We defined chronic kidney disease as persistent albuminuria or estimated GFR less than $60 \mathrm{~mL} / \mathrm{min}$ per $1.73 \mathrm{~m}^{2}$ (1). We classified chronic kidney disease according to our previously defined estimated GFR stages. We compared distributions of estimated GFR, estimated GFR stages, and prevalence of chronic kidney disease for both equations.

We performed the analyses by using Stata, version 10.0 (StataCorp, College Station, Texas), and incorporated the sampling weights from the complex NHANES sampling design to obtain unbiased estimates. We obtained standard errors for all estimates by using the Taylor series (linearization) method and followed NHANES-recommended procedures and weights (35-37). We used bootstrap methods implemented in Stata to derive CIs for the prevalence estimates for chronic kidney disease stages, incorporating persistence data on albuminuria. We applied prevalence estimates to the 2000 U.S. Census data to estimate the number of persons with chronic kidney disease in the United States.

\section{Role of the Funding Source}

The study was funded by a cooperative agreement with the National Institute of Diabetes and Digestive and Kidney Diseases, which allows them substantial involvement in the design of the study and in the collection, analysis, and interpretation of the data. The funding source was not required to approve publication of the finished manuscript.

\section{RESULTS}

\section{Selection of Studies and Clinical Characteristics}

Table 1 shows the clinical characteristics of the participants in each data set. In the development data set, mean measured GFR was $68 \mathrm{~mL} / \mathrm{min}$ per $1.73 \mathrm{~m}^{2}$ (SD, 40) and ranged from 2 to $190 \mathrm{~mL} / \mathrm{min}$ per $1.73 \mathrm{~m}^{2}$. The external validation data set had similar mean measured GFR, sex, and proportion of diabetes to the development and internal validation data sets but differed in age; body size; and the proportion of ethnic and racial minorities, kidney donors, and organ transplant recipients.

\section{Description of the CKD-EPI Equation}

The CKD-EPI equation for estimating log GFR includes log serum creatinine (modeled as a 2-slope linear spline with sex-specific knots at $62 \mu \mathrm{mol} / \mathrm{L}[0.7 \mathrm{mg} / \mathrm{dL}]$ in women and $80 \mu \mathrm{mol} / \mathrm{L}[0.9 \mathrm{mg} / \mathrm{dL}]$ in men), sex, race, and age on the natural scale. In comparison, the MDRD Study equation includes log serum creatinine without a spline, sex, race, and age on the log scale (Appendix Table 5, available at www.annals.org). The spline for log serum creatinine in the CKD-EPI equation allows steeper and identical slopes of GFR versus serum creatinine for men and women at creatinine levels above the knots and less steep and different slopes for men and women at creatinine levels below the knots. The slope for the CKD-EPI equation is similar to that of the MDRD Study equation above the knots but less steep below the knots, which leads to higher estimated GFR at lower creatinine values. The coefficient for black persons is greater than 1.0 in both equations, which leads to a higher estimated GFR for blacks than white persons at all levels of serum creatinine; however, the CKD-EPI equation yields a smaller difference in estimated GFR between black persons and white persons than does the MDRD Study equation. In the CKD-EPI equation, the relationship between GFR and sex varies by serum creatinine level. For example, the predicted femaleto-male ratio for estimated GFR varies from 0.83 to 0.92 when the serum creatinine level is between 44 and 71 $\mu \mathrm{mol} / \mathrm{L}(0.5$ and $0.8 \mathrm{mg} / \mathrm{dL})$ and is 0.75 when the serum creatinine level is greater than $80 \mu \mathrm{mol} / \mathrm{L}(>0.9 \mathrm{mg} / \mathrm{dL})$. However, it is constant at 0.74 for all serum creatinine values in the MDRD Study equation. Estimated GFR is inversely related to age in both equations, but at older ages, the age term on the natural scale in the CKD-EPI equation leads to lower estimated GFR for the same creatinine level than does the log age term in the MDRD Study equation. In the external validation data set, models with additional variables for diabetes, organ transplantation, weight, or interactions among variables did not substantially improve per-

\section{Table 2. The CKD-EPI Equation for Estimating GFR on the Natural Scale*}

$\begin{array}{cll}\text { Race and Sex } & \begin{array}{l}\text { Serum } \\ \text { Creatinine } \\ \text { Level, } \\ \boldsymbol{\mu m o l} / \mathrm{L} \\ (\mathbf{m g} / \mathrm{dL})\end{array} & \text { Equation } \\ & & \\ \text { Black } & \leq 62(\leq 0.7) & \text { GFR }=166 \times(\mathrm{Scr} / 0.7)^{-0.329} \times(0.993)^{\text {Age }} \\ \text { Female } & >62(>0.7) & \text { GFR }=166 \times(\mathrm{Scr} / 0.7)^{-1.209} \times(0.993)^{\text {Age }} \\ \text { Male } & \leq 80(\leq 0.9) & \text { GFR }=163 \times(\mathrm{Scr} / 0.9)^{-0.411} \times(0.993)^{\text {Age }} \\ & >80(>0.9) & \text { GFR }=163 \times(\mathrm{Scr} / 0.9)^{-1.209} \times(0.993)^{\text {Age }} \\ \text { White or other } & & \\ \text { Female } & \leq 62(\leq 0.7) & \text { GFR }=144 \times(\mathrm{Scr} / 0.7)^{-0.329} \times(0.993)^{\text {Age }} \\ \text { Male } & >62(>0.7) & \text { GFR }=144 \times(\mathrm{Scr} / 0.7)^{-1.209} \times(0.993)^{\text {Age }} \\ & \leq 80(\leq 0.9) & \text { GFR }=141 \times(\mathrm{Scr} / 0.9)^{-0.411} \times(0.993)^{\text {Age }} \\ & >80(>0.9) & \text { GFR }=141 \times(\mathrm{Scr} / 0.9)^{-1.209} \times(0.993)^{\text {Age }}\end{array}$

CKD-EPI = Chronic Kidney Disease Epidemiology Collaboration; GFR $=$ glomerular filtration rate.

* Expressed for specified race, sex, and serum creatinine level. To convert GFR from $\mathrm{mL} / \mathrm{min}$ per $1.73 \mathrm{~m}^{2}$ to $\mathrm{mL} / \mathrm{s}$ per $1.73 \mathrm{~m}^{2}$, multiply by 0.0167 . We derived equation coefficients from pooled development and internal validation data sets. The CKD-EPI equation, expressed as a single equation, is GFR $=141 \times$ $\min (\mathrm{Scr} / \kappa, 1)^{\alpha} \times \max (\mathrm{Scr} / \kappa, 1)^{-1.209} \times 0.993^{\text {Age }} \times 1.018$ [if female] $\times 1.159$ [if black], where Scr is serum creatinine, $\kappa$ is 0.7 for females and 0.9 for males, $\alpha$ is -0.329 for females and -0.411 for males, min indicates the minimum of Scr/ $\kappa$ or 1 , and max indicates the maximum of $\mathrm{Scr} / \kappa$ or 1 . In this table, the multiplication factors for race and sex are incorporated into the intercept, which results in different intercepts for age and sex combinations. 
Figure. Performance of the CKD-EPI and MDRD Study equations in estimating measured GFR in the external validation data set.
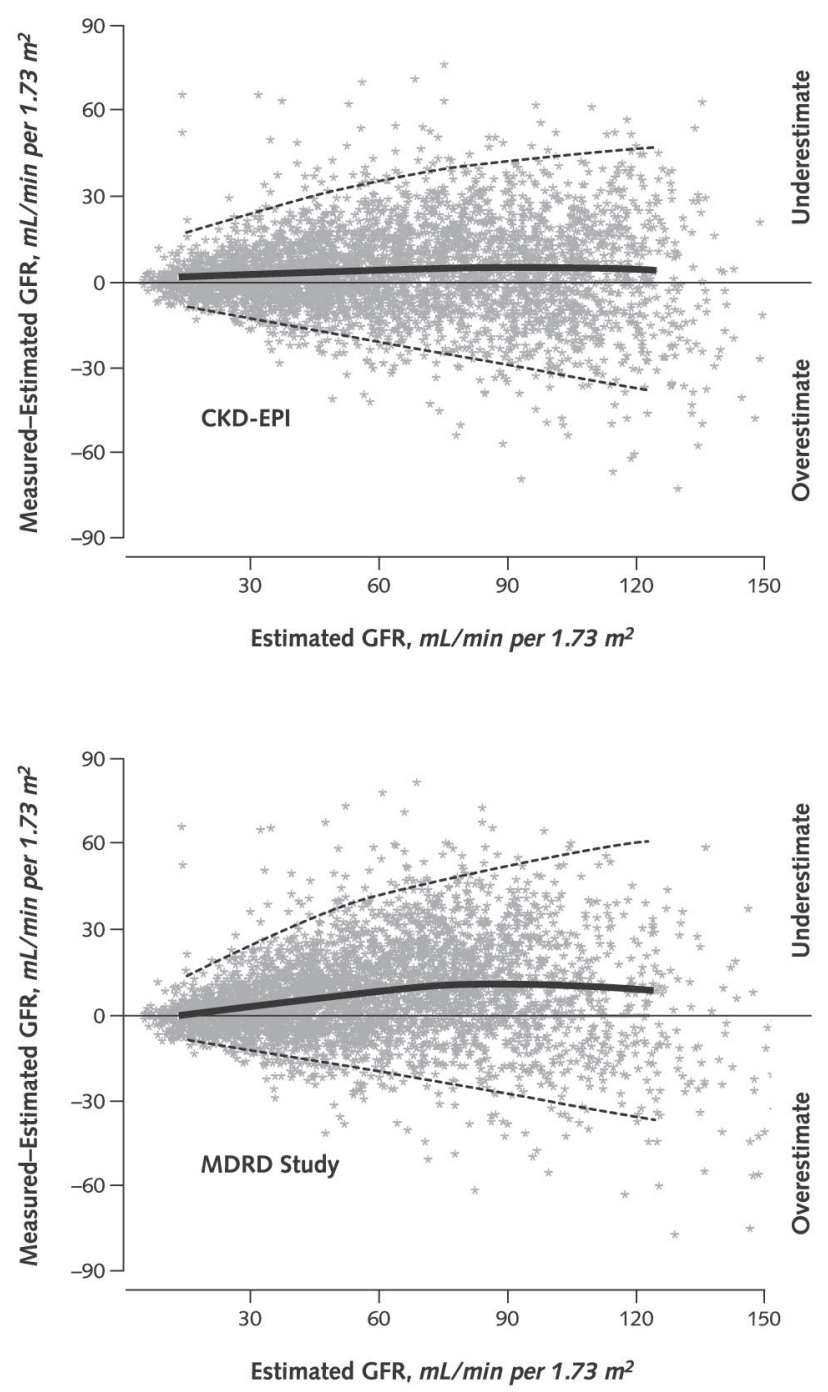

Both panels show the difference between measured and estimated versus estimated GFR. A smoothed regression line is shown with the 95\% CI (computed by using the lowest smoothing function in R), using quantile regression, excluding the lowest and highest $2.5 \%$ of estimated GFR. To convert GFR from $\mathrm{mL} / \mathrm{min}$ per $1.73 \mathrm{~m}^{2}$ to $\mathrm{mL} / \mathrm{s}$ per $\mathrm{m}^{2}$, multiply by 0.0167. CKI-EPD $=$ Chronic Kidney Disease Epidemiology Collaboration; GFR = glomerular filtration rate; MDRD = Modification of Diet in Renal Disease.

formance compared with the simpler models. Table 2 shows the CKD-EPI equation in a form that could be implemented in clinical laboratories.

\section{Comparison of Performance}

The Figure and Table 3 show the performance of both equations in the validation data set. (Appendix Table 6, available at www.annals.org, shows performance in the development and internal validation data sets.) The CKD-
EPI equation yielded improved median difference (bias), IQR, $P_{30}$, and root mean square error $(P<0.001$ for all). The CKD-EPI equation was as accurate as the MDRD Study equation in the subgroup with estimated GFR less than $60 \mathrm{~mL} / \mathrm{min}$ per $1.73 \mathrm{~m}^{2}$ and substantially more accurate in the subgroup with estimated GFR greater than 60 $\mathrm{mL} / \mathrm{min}$ per $1.73 \mathrm{~m}^{2}$. Results were consistent across studies and subgroups defined by age, sex, race, diabetes, transplant status, and body mass index (data not shown).

The ROC curves to detect GFR less than 90, 75, 60, 45,30 and $15 \mathrm{~mL} / \mathrm{min}$ per $1.73 \mathrm{~m}^{2}$ did not differ between the CKD-EPI and MDRD Study equations. The areas under the ROC curves were $0.95,0.96,0.96,0.97,0.97$, and 0.98 , respectively, for both equations. For detection of measured GFR less than $60 \mathrm{~mL} / \mathrm{min}$ per $1.73 \mathrm{~m}^{2}$, the estimated GFR value with highest combination of sensitivity and specificity was $59 \mathrm{~mL} / \mathrm{min}$ per $1.73 \mathrm{~m}^{2}$ for the CKD-EPI equation and $55 \mathrm{~mL} / \mathrm{min}$ per $1.73 \mathrm{~m}^{2}$ for the MDRD Study equation. The sensitivity and specificity of estimated GFR less than $60 \mathrm{~mL} / \mathrm{min}$ per $1.73 \mathrm{~m}^{2}$ were $91 \%$ and $87 \%$ according to the CKD-EPI equation and $95 \%$ and $82 \%$ according to the MDRD Study equation $(P<0.001$ for both comparisons). Concordance of estimated and measured GFR stages was $69 \%$ for the CKDEPI equation and $64 \%$ for the MDRD Study equation $(P<0.001)$. Table 4 shows classification of GFR stages estimated by the CKD-EPI and MDRD Study equations, with significant $(P<0.001)$ reclassification to higher values by the CKD-EPI equation at values of 30 to 59 $\mathrm{mL} / \mathrm{min}$ per $1.73 \mathrm{~m}^{2}$ and higher. Among those classified differently by the 2 equations, classification by the CKDEPI equation was correct more often than classification by the MDRD Study equation $(63 \%$ vs. $34 \%$; $P<0.001)$. Overall, our results indicate better classification by estimated GFR with the CKD-EPI equation, primarily because of reduction in bias.

\section{Comparison of Estimated GFR and Prevalence of Chronic Kidney Disease in NHANES}

The transformations and coefficients for variables in the CKD-EPI equation translate into differences in the estimated GFR distribution and prevalence of chronic kidney disease among NHANES participants from 1999 to 2006 compared with the MDRD Study equation. Both equations show a similar distribution at estimated GFR less than $45 \mathrm{~mL} / \mathrm{min}$ per $1.73 \mathrm{~m}^{2}$, but the CKD-EPI equation leads to a shift to the right at higher levels of estimated GFR (Appendix Figure 2, top, available at www.annals .org). Mean estimated GFR ( \pm SE) was $93.2 \pm 0.39$ using the CKD-EPI equation versus $86.3 \pm 0.40 \mathrm{~mL} / \mathrm{min}$ per $1.73 \mathrm{~m}^{2}$ using the MDRD Study equation (median, 94.5 $\mathrm{mL} / \mathrm{min}$ per $1.73 \mathrm{~m}^{2}$ [IQR, 79.7 to $108.1 \mathrm{~mL} / \mathrm{min}$ per $1.73 \mathrm{~m}^{2}$ ] versus $85.0 \mathrm{~mL} / \mathrm{min}$ per $1.73 \mathrm{~m}^{2}$ [IQR, 72.9 to $98.5 \mathrm{~mL} / \mathrm{min}$ per $\left.1.73 \mathrm{~m}^{2}\right]$ ). Comparison of classification of stages of estimated GFR showed reclassification to higher values with the CKD-EPI equation at values of 30 
to $59 \mathrm{~mL} / \mathrm{min}$ per $1.73 \mathrm{~m}^{2}$ and higher (Appendix Table 7, available at www.annals.org). We observed similar reclassification of estimated GFR distribution among patients with and without albuminuria (Appendix Table 8, available at www.annals.org).

The CKD-EPI equation yields a lower estimated prevalence of chronic kidney disease than the MDRD Study equation $(11.5 \%$ [CI, $10.6 \%$ to $12.4 \%$ ] vs. $13.1 \%$ [CI, $12.1 \%$ to $14.0 \%])$, primarily because of a lower estimated prevalence of stage 3 disease (6.3\% [CI, $5.8 \%$ to $6.9 \%$ ] vs. $7.8 \%$ [CI, $7.2 \%$ to $8.5 \%$ ]) (Appendix Figure 2, bottom, available at www .annals.org). Reclassification to higher estimated GFR leads to a higher prevalence of stage 1 disease and a lower prevalence of stage 2 disease. The CKD-EPI equation leads to a lower prevalence in women and white persons, such that the prevalence of stage 3 or 4 disease is not significantly higher in women versus men or in white persons versus black persons, as it is in the MDRD Study (data not shown). The prevalence of chronic kidney disease increases with age when either equation is used, but among patients older than 70 years, the CKD-EPI equation leads to a similar rather than lower estimated prevalence of chronic kidney disease. On the basis of the 2000 U.S. population of 201 million people older than 20 years, the CKD-EPI equation yields a prevalence of chronic kidney disease of 23.2 million (CI, 21.3 to 25.0 million), approximately 3 million fewer than that yielded by the MDRD Study equation (Appendix Table 9, available at www .annals.org).

\section{DISCUSSION}

We developed a new equation, the CKD-EPI equation, to estimate GFR in adults from serum creatinine by using a large database pooled from 10 studies. Using data pooled from 16 additional studies, we validated the CKD-EPI equation and showed that it is more accurate than the widely used MDRD Study equation. The CKD-EPI equation has lower bias, especially at an estimated GFR greater than $60 \mathrm{~mL} / \mathrm{min}$ per $1.73 \mathrm{~m}^{2}$; however, precision remains limited. The improved accuracy of the CKD-EPI equation overcomes some of the limitations of the MDRD Study equation and has important implications for public health and clinical practice.

The lower bias at higher estimated GFR reflects our use of a spline term for serum creatinine. The spline accounts for a weaker relationship between creatinine and GFR at lower creatinine levels than at higher levels, which is consistent with reports from studies primarily comprising patients with higher measured GFR, such as kidney donors and young people with type 1 diabetes without microalbuminuria $(10,15,38)$. Like the MDRD Study equation, the CKD-EPI equation includes age, race, and sex as surrogates for non-GFR determinants of serum creatinine. These variables are associated with muscle mass, the main determinant of creatinine generation (39). The imprecision of GFR estimates suggests that age, race, and sex do not account for all variation in non-GFR determinants of serum creatinine.

The CKD-EPI equation should lead to more accurate estimates of the distribution of estimated GFR and the burden of chronic kidney disease in the U.S. population. Median estimated GFR was $9.5 \mathrm{~mL} / \mathrm{min}$ per $1.73 \mathrm{~m}^{2}$ higher, which decreases the prevalence estimate for chronic kidney disease by $1.6 \%(11.5 \%$ vs. $13.1 \%$ using the MDRD Study equation). The high prevalence estimates for elderly persons, women, and white persons, compared with the low incidence rates of treated kidney failure in these groups, have raised concern about the use of the

Table 3. Comparison of the CKD-EPI and MDRD Study Equations in Estimating Measured GFR in the Validation Data Set*

\begin{tabular}{|c|c|c|c|}
\hline Variable and Equation & All Patients & $\begin{array}{l}\text { Patients With Estimated GFR } \\
<60 \mathrm{~mL} / \mathrm{min} \text { per } 1.73 \mathrm{~m}^{2}\end{array}$ & $\begin{array}{l}\text { Patients With Estimated GFR } \\
\geq 60 \mathrm{~mL} / \mathrm{min} \text { per } 1.73 \mathrm{~m}^{2}\end{array}$ \\
\hline \multicolumn{4}{|c|}{ Median difference $(95 \% \mathrm{Cl}), \mathrm{mL} / \mathrm{min}$ per $1.73 \mathrm{~m}^{2} \dagger$} \\
\hline CKD-EPI & $2.5(2.1-2.9)$ & $2.1(1.7-2.4)$ & $3.5(2.6-4.5)$ \\
\hline MDRD Study & $5.5(5.0-5.9)$ & $3.4(2.9-4.0)$ & $10.6(9.8-11.3)$ \\
\hline \multicolumn{4}{|c|}{$\begin{array}{l}\text { Interquartile range for differences }(95 \% \mathrm{Cl}) \text {, } \\
\qquad \mathrm{mL} / \mathrm{min} \text { per } 1.73 \mathrm{~m}^{2} \ddagger\end{array}$} \\
\hline CKD-EPI & $16.6(15.9-17.3)$ & $11.3(10.7-12.1)$ & $24.2(22.8-25.3)$ \\
\hline MDRD Study & $18.3(17.4-19.3)$ & $12.9(12.0-13.6)$ & $25.7(24.4-27.1)$ \\
\hline \multicolumn{4}{|l|}{$P_{30}(95 \% \mathrm{Cl}), \% \S$} \\
\hline CKD-EPI & $84.1(83.0-85.3)$ & $79.9(78.1-81.7)$ & $88.3(86.9-89.7)$ \\
\hline MDRD Study & $80.6(79.5-82.0)$ & $77.2(75.5-79.0)$ & $84.7(83.0-86.3)$ \\
\hline \multicolumn{4}{|c|}{ Root mean square error $(95 \% \mathrm{Cl})$} \\
\hline CKD-EPI & $0.250(0.241-0.259)$ & $0.284(0.270-0.298)$ & $0.213(0.203-0.223)$ \\
\hline MDRD Study & $0.274(0.265-0.283)$ & $0.294(0.280-0.308)$ & $0.248(0.238-0.258)$ \\
\hline
\end{tabular}

CKD-EPI = Chronic Kidney Disease Epidemiology Collaboration; GFR = glomerular filtration rate; MDRD = Modification of Diet in Renal Disease.

* To convert GFR from $\mathrm{mL} / \mathrm{min}$ per $1.73 \mathrm{~m}^{2}$ to $\mathrm{mL} / \mathrm{s}$ per $1.73 \mathrm{~m}^{2}$, multiply by 0.0167 .

† Median difference refers to measured GFR minus estimated GFR.

¥ Interquartile range refers to the $25-75$ th percentile.

$\S \mathrm{P}_{30}$ refers to percentage of GFR estimates that are within $30 \%$ of measured GFR. 
ARTICLE $\mid$ Development and Comparison of a New Equation to Estimate GFR

\begin{tabular}{|c|c|c|c|c|c|c|}
\hline \multirow{2}{*}{$\begin{array}{l}\text { CKD-EPI-Estimated GFR and } \\
\text { Measured GFR }\end{array}$} & \multicolumn{5}{|c|}{ MDRD Study-Estimated GFR, $n(\%)$} & \multirow{2}{*}{$\begin{array}{l}\text { Total Patients, } \\
n(\%)\end{array}$} \\
\hline & $\begin{array}{l}>90 \mathrm{~mL} / \mathrm{min} \\
\text { per } 1.73 \mathrm{~m}^{2}\end{array}$ & $\begin{array}{l}60-89 \mathrm{~mL} / \mathrm{min} \\
\text { per } 1.73 \mathrm{~m}^{2}\end{array}$ & $\begin{array}{l}30-59 \mathrm{~mL} / \mathrm{min} \\
\text { per } 1.73 \mathrm{~m}^{2}\end{array}$ & $\begin{array}{l}15-29 \mathrm{~mL} / \mathrm{min} \\
\text { per } 1.73 \mathrm{~m}^{2}\end{array}$ & $\begin{array}{l}<15 \mathrm{~mL} / \mathrm{min} \\
\text { per } 1.73 \mathrm{~m}^{2}\end{array}$ & \\
\hline $\begin{array}{l}\text { Estimated GFR }>90 \mathrm{~mL} / \mathrm{min} \text { per } 1.73 \mathrm{~m}^{2} \\
\text { Measured GFR }\end{array}$ & $670(17.2)$ & $319(8.2)$ & 0 & 0 & 0 & $989(25.4)$ \\
\hline$>90 \mathrm{~mL} / \mathrm{min}$ per $1.73 \mathrm{~m}^{2}$ & $586(15.0)$ & $221(5.7)$ & & & & \\
\hline $60-89 \mathrm{~mL} / \mathrm{min}$ per $1.73 \mathrm{~m}^{2}$ & 75 (1.9) & $93(2.4)$ & & & & \\
\hline $30-59 \mathrm{~mL} / \mathrm{min}$ per $1.73 \mathrm{~m}^{2}$ & $9(0.3)$ & $4(0.1)$ & & & & \\
\hline $15-29 \mathrm{~mL} / \mathrm{min}$ per $1.73 \mathrm{~m}^{2}$ & 0 & $1(0.0)$ & & & & \\
\hline$<15 \mathrm{~mL} / \mathrm{min}$ per $1.73 \mathrm{~m}^{2}$ & 0 & 0 & & & & \\
\hline $\begin{array}{l}\text { Estimated GFR } 60-89 \mathrm{~mL} / \mathrm{min} \text { per } 1.73 \mathrm{~m}^{2} \\
\text { Measured GFR }\end{array}$ & $2(0.0)$ & $803(20.6)$ & $190(4.9)$ & 0 & 0 & $995(25.5)$ \\
\hline$>90 \mathrm{~mL} / \mathrm{min}$ per $1.73 \mathrm{~m}^{2}$ & 0 & $263(6.8)$ & $11(0.3)$ & & & \\
\hline $60-89 \mathrm{~mL} / \mathrm{min}$ per $1.73 \mathrm{~m}^{2}$ & $1(0.0)$ & $459(11.8)$ & $110(2.8)$ & & & \\
\hline $30-59 \mathrm{~mL} / \mathrm{min}$ per $1.73 \mathrm{~m}^{2}$ & $1(0.0)$ & $77(2.0)$ & $69(1.8)$ & & & \\
\hline $15-29 \mathrm{~mL} / \mathrm{min}$ per $1.73 \mathrm{~m}^{2}$ & 0 & $4(0.1)$ & 0 & & & \\
\hline$<15 \mathrm{~mL} / \mathrm{min}$ per $1.73 \mathrm{~m}^{2}$ & 0 & 0 & 0 & & & \\
\hline $\begin{array}{l}\text { Estimated GFR } 30-59 \mathrm{~mL} / \mathrm{min} \text { per } 1.73 \mathrm{~m}^{2} \\
\text { Measured GFR }\end{array}$ & 0 & $2(0.0)$ & $1251(32.1)$ & $42(1.1)$ & 0 & $1295(33.2)$ \\
\hline$>90 \mathrm{~mL} / \mathrm{min}$ per $1.73 \mathrm{~m}^{2}$ & & 0 & $118(3.0)$ & 0 & & \\
\hline $60-89 \mathrm{~mL} / \mathrm{min}$ per $1.73 \mathrm{~m}^{2}$ & & $2(0.0)$ & $221(5.7)$ & 0 & & \\
\hline $30-59 \mathrm{~mL} / \mathrm{min}$ per $1.73 \mathrm{~m}^{2}$ & & 0 & $903(23.7)$ & $20(0.5)$ & & \\
\hline $15-29 \mathrm{~mL} / \mathrm{min}$ per $1.73 \mathrm{~m}^{2}$ & & 0 & $105(2.7)$ & $21(0.5)$ & & \\
\hline$<15 \mathrm{~mL} / \mathrm{min}$ per $1.73 \mathrm{~m}^{2}$ & & 0 & $4(0.1)$ & 0 & & \\
\hline $\begin{array}{l}\text { Estimated GFR } 15-29 \mathrm{~mL} / \mathrm{min} \text { per } 1.73 \mathrm{~m}^{2} \\
\text { Measured GFR }\end{array}$ & 0 & 0 & $9(0.2)$ & $462(11.9)$ & $2(0.0)$ & $473(12.1)$ \\
\hline$>90 \mathrm{~mL} / \mathrm{min}$ per $1.73 \mathrm{~m}^{2}$ & & & 0 & 0 & 0 & \\
\hline $60-89 \mathrm{~mL} / \mathrm{min}$ per $1.73 \mathrm{~m}^{2}$ & & & 0 & 0 & 0 & \\
\hline $30-59 \mathrm{~mL} / \mathrm{min}$ per $1.73 \mathrm{~m}^{2}$ & & & $5(0.1)$ & $109(2.8)$ & $1(0.0)$ & \\
\hline $15-29 \mathrm{~mL} / \mathrm{min}$ per $1.73 \mathrm{~m}^{2}$ & & & $4(0.1)$ & $302(7.8)$ & $1(0.0)$ & \\
\hline$<15 \mathrm{~mL} / \mathrm{min}$ per $1.73 \mathrm{~m}^{2}$ & & & 0 & $51(1.3)$ & 0 & \\
\hline $\begin{array}{l}\text { Estimated GFR }<15 \mathrm{~mL} / \mathrm{min} \text { per } 1.73 \mathrm{~m}^{2} \\
\text { Measured GFR }\end{array}$ & 0 & 0 & 0 & $5(0.1)$ & $139(3.6)$ & $144(3.7)$ \\
\hline$>90 \mathrm{~mL} / \mathrm{min}$ per $1.73 \mathrm{~m}^{2}$ & & & & 0 & 0 & \\
\hline $60-89 \mathrm{~mL} / \mathrm{min}$ per $1.73 \mathrm{~m}^{2}$ & & & & 0 & $2(0.0)$ & \\
\hline $30-59 \mathrm{~mL} / \mathrm{min}$ per $1.73 \mathrm{~m}^{2}$ & & & & 0 & 0 & \\
\hline $15-29 \mathrm{~mL} / \mathrm{min}$ per $1.73 \mathrm{~m}^{2}$ & & & & $2(0.0)$ & $32(0.8)$ & \\
\hline$<15 \mathrm{~mL} / \mathrm{min}$ per $1.73 \mathrm{~m}^{2}$ & & & & $3(0.1)$ & $105(2.7)$ & \\
\hline Total & $672(17.3)$ & $1124(28.9)$ & $1450(37.2)$ & $509(13.1)$ & $141(3.6)$ & $3896(100)$ \\
\hline
\end{tabular}

CKD-EPI = Chronic Kidney Disease Epidemiology Collaboration; GFR $=$ glomerular filtration rate; MDRD $=$ Modification of Diet in Renal Disease .

* Cell percentages may not total to margin percents because of rounding. Shaded cells represent agreement. Cells above the shaded diagonal cells represent disagreements in which estimated GFR category was higher with the CKD-EPI equation than with the MDRD Study equation; cells below the shaded diagonal cells represent disagreements in which estimated GFR category was lower. To convert GFR from $\mathrm{mL} / \mathrm{min}$ per $1.73 \mathrm{~m}^{2}$ to $\mathrm{mL} / \mathrm{s}$ per $1.73 \mathrm{~m}^{2}$, multiply by 0.0167 .

MDRD Study equation $(7,40,41)$. When the CKD-EPI equation is used, the prevalence is reduced in women and white persons but remains high in elderly persons. Possible explanations for the remaining disparities between prevalence and incidence include competing risk from fatal cardiovascular disease in elderly persons and faster progression of kidney disease in men and black persons $(42,43)$.

The greater accuracy of the CKD-EPI equation should improve clinical decision making in patients with decreased kidney function. In particular, lower bias should reduce the rate of false-positive diagnoses of stage 3 chronic kidney disease (estimated GFR $<60 \mathrm{~mL} / \mathrm{min}$ per $1.73 \mathrm{~m}^{2}$ ) in patients without chronic kidney disease (measured GFR $>60 \mathrm{~mL} / \mathrm{min}$ per $1.73 \mathrm{~m}^{2}$ and no markers of kidney damage). Patients with chronic kidney disease are at higher risk for various complications (44-50), and guidelines and recommendations call for reducing the dosage of drugs excreted by the kidney, avoiding contrast media for imaging procedures and phosphate-based enemas in preparation for colonoscopy, and setting lower targets for cardiovascular risk factors in patients with decreased GFR. Falsely low estimated GFRs could therefore lead to insufficient drug dosing, withholding of important diagnostic tests, and overaggressive cardiovascular risk factor reduction in patients without chronic kidney disease. The effect of more accurate estimates at higher GFRs on clinical decision making should be evaluated.

The strengths of our study include its design, with separate large data sets for development and validation of the new equation, and a prespecified rigorous statistical analytical plan for introduction and testing of all variables in the development data set. The pooled development and validation data sets include participants with diverse clinical characteristics, with and without kidney disease, and across a wide range of measured GFR, which allows more 
general applicability than does the MDRD Study equation. Comparison of equations in a separate validation data set overcomes limitations of differences among studies in patient characteristics and methods for measurement of GFR and serum creatinine.

Our study also has limitations. First, a single equation is unlikely to work equally well in all populations. Second, we have pooled studies of different populations to develop and validate the CKD-EPI equation. We performed extensive analyses to examine possible study effects but cannot rule out that some of our findings may reflect the specific studies we included in our database. Third, our study sample is not representative of the general population because few participants had a higher GFR and relatively few participants were older than 70 years or of racial minorities other than black (who are at increased risk for chronic kidney disease). Fourth, we had incomplete data on diabetes type, immunosuppressive agents for transplantation, measures of muscle mass, and other clinical conditions and medications that might affect serum creatinine independent of GFR; however, the variables that we evaluated are the most readily available and easy to ascertain for widespread clinical application. Fifth, the CKD-EPI equation is more complex than the MDRD Study equation, but it can readily be implemented into clinical laboratory information systems by using the same input variables required for the MDRD Study equation. Finally, our equation does not overcome the limitations of serum creatinine as an endogenous filtration marker. All creatinine-based equations should be used with caution in people with abnormally high or low muscle mass. Nevertheless, serum creatinine is currently central for clinical assessment of kidney function, and GFR estimates based on serum creatinine will continue to be used in clinical practice for the foreseeable future.

Further research is needed to improve GFR estimation. Imprecision in GFR estimates may be secondary to non-GFR determinants of creatinine. Measurement errors in GFR may also inflate measures of imprecision. Research should be directed toward improving GFR measurement and evaluating cystatin C and novel filtration markers for GFR estimation, either alone or in combination with serum creatinine (51). Studies of representative samples, especially elderly persons and racial and ethnic minorities, are necessary.

In summary, the CKD-EPI creatinine equation is more accurate than the MDRD Study equation across various study populations and clinical conditions. Bias is improved, especially at higher estimated GFRs, although precision remains suboptimal. Improved accuracy of the CKD-EPI equation could have important implications for public health and clinical practice. We suggest that the CKD-EPI equation could replace the MDRD Study equation in general clinical use to estimate GFR.

From Tufts Medical Center, Boston, Massachusetts; Johns Hopkins University, Baltimore, Maryland; University of Pennsylvania School of Medicine, Philadelphia, Pennsylvania; National Institutes of Health, Be- thesda, Maryland; Cleveland Clinic Foundation, Cleveland, Ohio; and University of Utah, Salt Lake City, Utah.

Acknowledgment: The authors thank Aghogho Okparavero, MBBS, $\mathrm{MPH}$, for his assistance in communications and manuscript preparation.

Grant Support: By grants UO1 DK 053869, UO1 DK 067651, and UO1 DK 35073 as part of a cooperative agreement with the National Institute of Diabetes and Digestive and Kidney Diseases.

Potential Financial Conflicts of Interest: Stock ownership or options (other than mutual funds): J.W. Kusek (Pfizer, Eli Lilly, DeCode Genetics).

Reproducible Research Statement: Study protocol: Available from Dr. Levey (address below). Statistical code and data set: Not available.

Requests for Single Reprints: Andrew S. Levey, MD, Division of Nephrology, Tufts Medical Center, 800 Washington Street, Box 391, Boston, MA 02111.

Current author addresses and author contributions are available at www .annals.org.

\section{References}

1. National Kidney Foundation. K/DOQI clinical practice guidelines for chronic kidney disease: evaluation, classification, and stratification. Am J Kidney Dis. 2002;39:S1-266. [PMID: 11904577]

2. Stevens LA, Coresh J, Greene T, Levey AS. Assessing kidney functionmeasured and estimated glomerular filtration rate. N Engl J Med. 2006;354: 2473-83. [PMID: 16760447]

3. Levey AS, Bosch JP, Lewis JB, Greene T, Rogers N, Roth D. A more accurate method to estimate glomerular filtration rate from serum creatinine: a new prediction equation. Modification of Diet in Renal Disease Study Group. Ann Intern Med. 1999;130:461-70. [PMID: 10075613]

4. Levey AS, Coresh J, Greene T, Stevens LA, Zhang YL, Hendriksen S, et al; Chronic Kidney Disease Epidemiology Collaboration. Using standardized serum creatinine values in the modification of diet in renal disease study equation for estimating glomerular filtration rate. Ann Intern Med. 2006;145:247-54. [PMID: 16908915]

5. Miller WG. Reporting estimated GFR: a laboratory perspective [Editorial]. Am J Kidney Dis. 2008;52:645-8. [PMID: 18805345]

6. Levey AS, Andreoli SP, DuBose T, Provenzano R, Collins AJ. CKD: common, harmful, and treatable-World Kidney Day 2007. Am J Kidney Dis. 2007; 49:175-9. [PMID: 17261418]

7. Coresh J, Selvin E, Stevens LA, Manzi J, Kusek JW, Eggers P, et al. Prevalence of chronic kidney disease in the United States. JAMA. 2007;298:2038-47. [PMID: 17986697]

8. Stevens LA, Coresh J, Feldman HI, Greene T, Lash JP, Nelson RG, et al. Evaluation of the modification of diet in renal disease study equation in a large diverse population. J Am Soc Nephrol. 2007;18:2749-57. [PMID: 17855641]

9. Lewis J, Agodoa L, Cheek D, Greene T, Middleton J, O'Connor D, et al; African-American Study of Hypertension and Kidney Disease. Comparison of cross-sectional renal function measurements in African Americans with hypertensive nephrosclerosis and of primary formulas to estimate glomerular filtration rate. Am J Kidney Dis. 2001;38:744-53. [PMID: 11576877]

10. Ibrahim H, Mondress M, Tello A, Fan Y, Koopmeiners J, Thomas W. An alternative formula to the Cockcroft-Gault and the modification of diet in renal diseases formulas in predicting GFR in individuals with type 1 diabetes. J Am Soc Nephrol. 2005;16:1051-60. [PMID: 15716336]

11. Nelson RG, Bennett PH, Beck GJ, Tan M, Knowler WC, Mitch WE, et al. Development and progression of renal disease in Pima Indians with non-insulindependent diabetes mellitus. Diabetic Renal Disease Study Group. N Engl J Med. 1996;335:1636-42. [PMID: 8929360]

12. Lewis EJ, Hunsicker LG, Bain RP, Rohde RD. The effect of angiotensinconverting-enzyme inhibition on diabetic nephropathy. The Collaborative Study Group. N Engl J Med. 1993;329:1456-62. [PMID: 8413456]

13. Feldman HI, Appel LJ, Chertow GM, Cifelli D, Cizman B, Daugirdas J, et al; Chronic Renal Insufficiency Cohort (CRIC) Study Investigators. The 
ArTICLE Development and Comparison of a New Equation to Estimate GFR

Chronic Renal Insufficiency Cohort (CRIC) Study: Design and Methods. J Am Soc Nephrol. 2003;14:S148-53. [PMID: 12819321]

14. Poggio ED, Wang X, Greene T, Van Lente F, Hall PM. Performance of the modification of diet in renal disease and Cockcroft-Gault equations in the estimation of GFR in health and in chronic kidney disease. J Am Soc Nephrol. 2005;16:459-66. [PMID: 15615823]

15. Rule AD, Larson TS, Bergstralh EJ, Slezak JM, Jacobsen SJ, Cosio FG. Using serum creatinine to estimate glomerular filtration rate: accuracy in good health and in chronic kidney disease. Ann Intern Med. 2004;141:929-37. [PMID: 15611490]

16. Gonwa TA, Jennings L, Mai ML, Stark PC, Levey AS, Klintmalm GB. Estimation of glomerular filtration rates before and after orthotopic liver transplantation: evaluation of current equations. Liver Transpl. 2004;10:301-9. [PMID: 14762871]

17. Chapman AB, Guay-Woodford LM, Grantham JJ, Torres VE, Bae KT, Baumgarten DA, et al; Consortium for Radiologic Imaging Studies of Polycystic Kidney Disease cohort. Renal structure in early autosomal-dominant polycystic kidney disease (ADPKD): The Consortium for Radiologic Imaging Studies of Polycystic Kidney Disease (CRISP) cohort. Kidney Int. 2003;64:1035-45. [PMID: 12911554]

18. Bosma RJ, Doorenbos CR, Stegeman CA, van der Heide JJ, Navis G. Predictive performance of renal function equations in renal transplant recipients: an analysis of patient factors in bias. Am J Transplant. 2005;5:2193-203. [PMID: 16095498]

19. Rook M, Hofker HS, van Son WJ, Homan van der Heide JJ, Ploeg RJ, Navis GJ. Predictive capacity of pre-donation GFR and renal reserve capacity for donor renal function after living kidney donation. Am J Transplant. 2006;6: 1653-9. [PMID: 16827867]

20. Grubb A, Nyman U, Björk J, Lindström V, Rippe B, Sterner G, et al. Simple cystatin C-based prediction equations for glomerular filtration rate compared with the modification of diet in renal disease prediction equation for adults and the Schwartz and the Counahan-Barratt prediction equations for children. Clin Chem. 2005;51:1420-31. [PMID: 15961546]

21. Mauer M, Drummond K. The early natural history of nephropathy in type 1 diabetes: I. Study design and baseline characteristics of the study participants. Diabetes. 2002;51:1572-9. [PMID: 11978658]

22. Froissart M, Rossert J, Jacquot C, Paillard M, Houillier P. Predictive performance of the modification of diet in renal disease and Cockcroft-Gault equations for estimating renal function. J Am Soc Nephrol. 2005;16:763-73. [PMID: 15659562]

23. Mauer M, Zinman B, Gardiner R, Drummond KN, Suissa S, Donnelly SM, et al. ACE-I and ARBs in early diabetic nephropathy. J Renin Angiotensin Aldosterone Syst. 2002;3:262-9. [PMID: 12584670]

24. Hansen HP, Tauber-Lassen E, Jensen BR, Parving HH. Effect of dietary protein restriction on prognosis in patients with diabetic nephropathy. Kidney Int. 2002;62:220-8. [PMID: 12081581]

25. Jacobsen P, Andersen S, Rossing K, Hansen BV, Parving HH. Dual blockade of the renin-angiotensin system in type 1 patients with diabetic nephropathy. Nephrol Dial Transplant. 2002;17:1019-24. [PMID: 12032191]

26. Jacobsen P, Andersen S, Rossing K, Jensen BR, Parving HH. Dual blockade of the renin-angiotensin system versus maximal recommended dose of ACE inhibition in diabetic nephropathy. Kidney Int. 2003;63:1874-80. [PMID: 12675866]

27. Mathiesen ER, Hommel E, Giese J, Parving HH. Efficacy of captopril in postponing nephropathy in normotensive insulin dependent diabetic patients with microalbuminuria. BMJ. 1991;303:81-7. [PMID: 1860008]

28. Tarnow L, Rossing P, Jensen C, Hansen BV, Parving HH. Long-term renoprotective effect of nisoldipine and lisinopril in type 1 diabetic patients with diabetic nephropathy. Diabetes Care. 2000;23:1725-30. [PMID: 11128341]

29. Levey AS, Coresh J, Greene T, Marsh J, Stevens LA, Kusek JW, et al; Chronic Kidney Disease Epidemiology Collaboration. Expressing the Modification of Diet in Renal Disease Study equation for estimating glomerular filtration rate with standardized serum creatinine values. Clin Chem. 2007;53:766-72. [PMID: 17332152]

30. Stevens LA, Manzi J, Levey AS, Chen J, Deysher AE, Greene T, et al. Impact of creatinine calibration on performance of GFR estimating equations in a pooled individual patient database. Am J Kidney Dis. 2007;50:21-35. [PMID: 17591522]

31. Generalized additive models. In: Chambers J, Hastie T, eds. Statistical Models. London: Chapman and Hall; 1993:104-54.

32. Efron B, Tibshirani RJ. An Introduction to the Bootstrap. New York: Chapman and Hall; 1993.
33. Selvin E, Manzi J, Stevens LA, Van Lente F, Lacher DA, Levey AS, et al. Calibration of serum creatinine in the National Health and Nutrition Examination Surveys (NHANES) 1988-1994, 1999-2004. Am J Kidney Dis. 2007;50: 918-26. [PMID: 18037092]

34. Coresh J, Astor BC, Greene T, Eknoyan G, Levey AS. Prevalence of chronic kidney disease and decreased kidney function in the adult US population: Third National Health and Nutrition Examination Survey. Am J Kidney Dis. 2003;41: 1-12. [PMID: 12500213]

35. Centers for Disease Control and Prevention. National Health and Nutrition Examination Survey (NHANES). Vol. 2007. Hyattsville, MD: National Center for Health Statistics; 2007.

36. National Center for Health Statistics. National Health and Nutrition Examination Survey (NHANES)_Analytic Guidelines. Vol. 2007. Hyattsville, MD: National Center for Health Statistics; 2007.

37. Analytic and Reporting Guidelines: The Third National Health and Nutrition Examination Survey, NHANES III (1988-94). Vol. 2007. Hyattsville, MD: National Center for Health Statistics; 2007.

38. Poggio ED, Wang X, Greene T, Van Lente F, Hall PM. Performance of the modification of diet in renal disease and Cockcroft-Gault equations in the estimation of GFR in health and in chronic kidney disease. J Am Soc Nephrol. 2005;16:459-66. [PMID: 15615823]

39. Perrone RD, Madias NE, Levey AS. Serum creatinine as an index of renal function: new insights into old concepts. Clin Chem. 1992;38:1933-53. [PMID: 1394976]

40. Glassock RJ, Winearls C. An epidemic of chronic kidney disease: fact or fiction? Nephrol Dial Transplant. 2008;23:1117-21. [PMID: 18359870]

41. U.S. Renal Data System. USRDS 2008 Annual Data Report: Atlas of Chronic Kidney Disease and End-Stage Renal Disease in the United States. Bethesda, MD: National Institutes of Health, National Institute of Diabetes and Digestive and Kidney Diseases; 2008. Accessed at www.usrds.org/adr.htm on 11 December 2008.

42. Coresh J, Stevens LA, Levey AS. Chronic kidney disease is common: what do we do next? Nephrol Dial Transplant. 2008;23:1122-5. [PMID: 18359871] 43. Hallan SI, Coresh J, Astor BC, Asberg A, Powe NR, Romundstad S, et al. International comparison of the relationship of chronic kidney disease prevalence and ESRD risk. J Am Soc Nephrol. 2006;17:2275-84. [PMID: 16790511] 44. Aronoff GR, Berns JS, Brier ME, Golper TA, Morrison G, Singer I, et al. Drug Prescribing in Renal Failure. Dosing Guidelines for Adults. 4th ed. Philadelphia: American Coll of Physicians; 1999.

45. Seliger SL, Zhan M, Hsu VD, Walker LD, Fink JC. Chronic kidney disease adversely influences patient safety. J Am Soc Nephrol. 2008;19:2414-9. [PMID: 18776123]

46. Benko A, Fraser-Hill M, Magner P, Capusten B, Barrett B, Myers A, et al; Canadian Association of Radiologists. Canadian Association of Radiologists: consensus guidelines for the prevention of contrast-induced nephropathy. Can Assoc Radiol J. 2007;58:79-87. [PMID: 17521052]

47. U.S. Food and Drug Administration. Information for Healthcare Professionals: Gadolinium-Based Contrast Agents for Magnetic Resonance Imaging (marketed as Magnevist, MultiHance, Omniscan, OptiMARK, ProHance). Silver Spring, MD: Center for Drug Evaluation and Research; 2008. Accessed at www .fda.gov/cder/drug/InfoSheets/HCP/gcca_200705.htm on 13 March 2009.

48. Khurana A, McLean L, Atkinson S, Foulks CJ. The effect of oral sodium phosphate drug products on renal function in adults undergoing bowel endoscopy. Arch Intern Med. 2008;168:593-7. [PMID: 18362251]

49. Hsu CY, Ordoñez JD, Chertow GM, Fan D, McCulloch CE, Go AS. The risk of acute renal failure in patients with chronic kidney disease. Kidney Int. 2008;74:101-7. [PMID: 18385668]

50. Sarnak MJ, Levey AS, Schoolwerth AC, Coresh J, Culleton B, Hamm LL, et al; American Heart Association Councils on Kidney in Cardiovascular Disease, High Blood Pressure Research, Clinical Cardiology, and Epidemiology and Prevention. Kidney disease as a risk factor for development of cardiovascular disease: a statement from the American Heart Association Councils on Kidney in Cardiovascular Disease, High Blood Pressure Research, Clinical Cardiology, and Epidemiology and Prevention. Circulation. 2003;108:2154-69. [PMID: 14581387]

51. Stevens LA, Coresh J, Schmid CH, Feldman HI, Froissart M, Kusek J, et al. Estimating GFR using serum cystatin $\mathrm{C}$ alone and in combination with serum creatinine: a pooled analysis of 3,418 individuals with CKD. Am J Kidney Dis. 2008;51:395-406. [PMID: 18295055] 


\section{Annals of Internal Medicine}

Current Author Addresses: Drs. Levey and Stevens and Ms. Zhang: Division of Nephrology, Tufts Medical Center, 800 Washington Street, Box 391, Boston, MA 02111.

Dr. Schmid: The Institute for Clinical Research and Health Policy Studies, Tufts Medical Center, 800 Washington Street, Box 063, Boston, MA 02111.

Mr. Castro and Dr. Coresh: Department of Epidemiology, Johns Hopkins Bloomberg School of Public Health, 2024 East Monument Street, Suite 2-600, Baltimore, MD 21205.

Dr. Feldman: Clinical Epidemiology Unit, University of Pennsylvania School of Medicine, 923 Blockley Hall, 423 Guardian Drive, Philadelphia, PA 19104.

Drs. Kusek and Eggers: Kidney and Urology Branch, National Institute of Diabetes and Digestive and Kidney Diseases, National Institutes of Health, 6707 Democracy Boulevard, Bethesda, MD 20817.

Dr. Van Lente: Department of Clinical Pathology, Cleveland Clinic Foundation, 9500 Euclid Avenue, Mail Code L11, Cleveland, $\mathrm{OH}$ 44195 .

Dr. Greene: Division of Clinical Epidemiology, 30 North 1900 East, Room AC221, Salt Lake City, UT 84132.
Author Contributions: Conception and design: A.S. Levey, L.A. Stevens, C.H. Schmid, H.I. Feldman, F. Van Lente, T. Greene, J. Coresh.

Analysis and interpretation of the data: A.S. Levey, L.A. Stevens, C.H. Schmid, H.I. Feldman, P. Eggers, F. Van Lente, T. Greene, J. Coresh.

Drafting of the article: A.S. Levey, C.H. Schmid, F. Van Lente, J. Coresh.

Critical revision of the article for important intellectual content: A.S. Levey, L.A. Stevens, C.H. Schmid, H.I. Feldman, J.W. Kusek, P. Eggers, T. Greene, J. Coresh.

Final approval of the article: A.S. Levey, L.A. Stevens, C.H. Schmid, Y. Zhang, H.I. Feldman, J.W. Kusek, T. Greene, J. Coresh.

Provision of study materials or patients: A.S. Levey.

Statistical expertise: C.H. Schmid, Y. Zhang, T. Greene, J. Coresh. Obtaining of funding: A.S. Levey, J.W. Kusek, P. Eggers, J. Coresh. Administrative, technical, or logistic support: A.S. Levey, L.A. Stevens, Y. Zhang, P. Eggers.

Collection and assembly of data: A.S. Levey, L.A. Stevens, Y. Zhang, F. Van Lente. 